\title{
DEVELOPING AND SUSTAINING CRITICAL REFLECTION IN TEACHER EDUCATION
}

\author{
John Smyth \\ Deakin University
}

\begin{abstract}
It is interesting to speculate on the reasons for the recent upsurge of interest in what might be broadly described as a reflective approach to teacher education. While there is a good deal of contention at the moment as to precisely what this might mean, it is clear that we have been down a very similar track before, most notably with the work of Dewey (1904/1965) earlier this century. So what makes the current revival so significant? For an answer to that question we have to look carefully at the social, economic, and political times in which we live and at the way in which the emphasis on reflective approaches represents something of a calculated response to the prevailing views about the nature of schooling and knowledge. There can be little doubt that as we rush headlong into this era of neoconservative ways of thinking and acting educationally, the reflective approach represents an interesting and challenging counter discourse to the ensconced technicist views. At the same time that we are being increasingly courted and urged by technologically minded policymakers and educational reformers into believing that all our social and economic ills will somehow magically dissolve if we place our faith in their capacity to get the mix of techniques right, significant questions are being asked as to whether the applied science mentality that lies behind their thinking and their strategies has the efficacy to resolve the complex issues in the ways being suggested.
\end{abstract}

It is clear that the work of Donald Schon in his Reflective Practitioner: How Professionals Think in Action (1983), and his more recent work, Educating the Reflective Practitioner (1987), has been important in all of this. Indeed, Schon's work has come to be something of a rallying point for besieged liberal progressive educators who are under tremendous threat at the moment as a consequence of educational conservatism. Connelly and Clandinin (1988) regard as remarkable "the speed with which Schon's . . . recent works [have] penetrated the reference lists of teacher education writers" (p. 1).

Schon's work does provide something of a convenient focus by which to reinforce and keep alive the tradition of experiential knowledge, but his substantive arguments are of major importance. In the face of widespread and continuing demands for technocratic ways of operating, Schon argues that proposals for more stringent forms of accountability based on research evidence are entirely wrongheaded. For Schon the problem has much more to do with a deep-seated "crisis of confidence" (as distinct from "competence") that amounts to a manifest inability of the professions to deliver solutions on the pressing environmental, economic, and social problems of our times. His claims are rooted in the argument that those who persist in arguing that professional practice should have a demonstrated 'scientific' basis and should adhere closely to prescriptions deriving from large-scale, objective, outsiderinitiated research ignore the extent to which practitioner-derived knowledge is, in fact, trustworthy and relevant in and of itself (see Smyth, 1987a). By choosing to focus exclusively on the products of other peoples' research, at the expense of the process by which understandings are reached, proponents of such views actually misconstrue the value of research, which lies not in its being definitive, but rather in the tentativeness of disciplinebased research as something to be explored, confirmed, or rejected in the light of experience. 
Continuing to seize upon the instrumental applicability of other people's research findings about professional practice is tantamount to placing a level of certainty on research that social scientists themselves would deny. Schon argues that across a range of professional areas, the nature of professional practice seems to have shifted from "problem solving" to "problem setting" (or problem posing); that is to say, from a rational process of choosing from among possibilities that best suit agreed-upon ends, to a situation that opens up for contestation and debate the nature of those decisions, the ends to which they are to be directed, and the means by which they are achievable (Schon, 1983). Rather than relying upon discipline-based knowledge, the scene, according to Schon is becoming increasingly characterized by the application of practitioner knowledge acquired from previous particular cases. What this amounts to is a quite dramatic shift: from a position where scientifically derived knowledge was deemed superior, to a circumstance in which artistic and intuitive knowledge may have a claim to being equally appropriate; from an a priori instrumental view of knowledge, to one that reflects knowledge as being tentative and problematic; and from a view that presupposes answers to complex social questions, to one that endorses the importance of problem posing and negotiated resolution (Smyth, 1986).

What Schon (1983) does is to provide us with a way of fundamentally re-thinking how we view professional practice, and the relationship between theory and practice. His thesis rests on the claim that whereas in the past, professionals laid claim to "extraordinary knowledge in matters of great social importance" (p. 4) and in return were granted unique rights and privileges, a number of factors have occurred to change those circumstances. In addition to the media exposure of the extensive misuse and abuse of these privileges for personal gain, Schon (1983) points to a more important public loss of confidence in and questioning by society of professionals' claims to extraordinary knowledge. Schon illustrates this by way of example:

a series of announced national crises - the deteriorating cities, poverty, the pollution of the environment, the shortage of energy - seemed to have roots in the very practices of science, technology, and public policy that were being called upon to alleviate them. ... Government sponsored 'wars' against such crises seemed not to produce the expected results; indeed, they often seemed to exacerbate the crises. (p.9)

Increasingly, professionals of all kinds (teachers included) are being confronted by situations in which the tasks they are required to perform no longer bear any relationship to the tasks for which they have been educated. As Schon (1983) so aptly put it, "The situations of practice are not problems to be solved but problematic situations characterized by uncertainty, disorder and indeterminacy" (pp. 15-16). Practitioners are therefore becoming increasingly engulfed in wrangles over conflicting and competing values and purposes. Teachers, for example, are

faced with pressures for increased efficiency in the context of contracting budgets, demands that they rigorously "teach the basics," exhortations to encourage creativity, build citizenship, (and to) help students examine their values. (p. 17)

\section{Impediments to Empowerment}

While it is true that this largely undefined call for a reflective approach to teacher education has occurred as a consequence of moves to empower teachers, particularly in a climate characterized by centralized authorities acting in ways to reduce teacher autonomy, many of these calls are remarkably unreflexive of their own agenda. Indeed, the way the 
term is picked up and used on some occasions generates major problems. Liston and Zeichner (1987) argue that reflection is becoming something of an "educational slogan. . that lacks sufficient conceptual elaboration and programmatic strength" (p. 2). As Gore (1987) points out, what happens in circumstances like these is that people like Cruickshank (1985) are able to use it as a way of appearing to give legitimation to a focus on the pedagogical and behavioral skills of teachers (or the means of teaching), to the exclusion of the ends of valued social and moral purposes to which teaching is (or should be) directed. For example, while Cruickshank and Applegate (1981) define reflection in terms of "helping teachers to think about what happened, why it happened, and what else they could have done to reach their goals" (p. 553), it is clear that their conception of the reflective amounts to nothing short of prescribing what teachers ought to teach within tight guidelines, while coopting one another into policing the implementation of predetermined goals. Activity of this kind gives the reflective approach a bad name.

Whether we are speaking about a reflective stance for experienced teachers or those in training, it is important that the process be clearly seen as based on moves that actively recognize and endorse the decidedly historical, political, theoretical, and moral nature of teaching. When teaching is removed from an analysis of contextual determinants like those within which it is located, it takes on the aura of a technical process. The notion of reflection, therefore, that I want to deal with here is not one that is related at all to passive deliberation or contemplation - a meaning that is sometimes ascribed to reflection in everyday life. Rather, what I am arguing for is a notion of the reflective in teacher education that is both active and militant (Mackie, 1981; Shor, 1987), that reintroduces into the discourse about teaching and schooling a concern for the "ethical, personal and political" (Beyer and Apple, 1988, p. 4), and that is above all concerned with infusing action with a sense of power and politics. Beyer and Apple (1988) put this succinctly:

It involves both conscious understanding of and actions in schools on solving our daily problems. These problems will not go away by themselves, after all. But it also requires critically reflective practices that alter the material and ideological conditions that cause the problems we are facing as educators in the first place. (p.4)

Clearly, the major impediment (but at the same time the major challenge) to the reflective approach envisaged above has been recent attempts to 'reform' schooling in the USA and other western democracies by ensuring that what goes on inside schools is directly responsive to the economic needs outside of schools. In large measure this has meant deliberately constructing the mythology that somehow schools and teachers are the cause of the economic failure, but that if certain narrowly prescribed forms of action (a return to the teaching of basic skills, better teacher appraisal schemes, tighter classroom discipline, longer school days, more sophisticated performance indicators, state-wide testing, performance budgeting, and other cost-efficient and cost-effectiveness measures) are adopted, then schools can be magically restored to their rightful role as servants of the economy (Walker and Barton, 1987). The claim of the policy-making technocrats is that it is just a matter of entrusting schools to them so that they can come up with the right mix of variables to be prescribed for teachers to follow in achieving the required strategic, economic, and social goals. It is precisely this kind of common-sense thinking that is in fact imbued with all manner of undisclosed political agendas that ought to be the object of discussion about teaching and teacher education. To paraphrase a comment by Dippo (1988), teacher education should provide practitioners with

the tools and resources they need to recognize, analyze, and address the contradictions, and in so doing open-up the possibility that conditions in schools. ... can be different .... [S]uch empowering educational goals 
[are] clearly linked to the larger political project of redefining existing socia' and economic relations. (p. 486)

Tom (1985) points out that while always a minority viewpoint, the reflective (or aquiryoriented) approach to teacher education goes back a long way, but the confusion that urises is with respect to what is defined as the "arena of the problematic." As Tom puts it, while there is a view that "to make teaching problematic is to raise doubts about what, under ordinary circumstances, appears to be effective or wise practice" (p. 37), the object of that problematizing (or reflective action) is by no means agreed upon. According to him, "the objects of our doubts might be accepted principles of good pedagogy, typical ways teachers respond to classroom management issues, customary beliefs about the relationship of schooling to society, or ordinary definitions of teacher authority -- both in the classroom and in the broader school context" (p. 37). Reflection can, therefore, vary from a concern with the micro aspects of the teaching-learning process and subject matter knowledge, to macro concerns about political/ethical principles in underlying teaching and the relationship of schooling to the wider institutions and hierarchies of society. How we conceptualize teaching, whether as a set of neutral, value-free technical acts, or as a set of ethical, moral, and political imperatives holds important implications for the kind of reflective stance we adopt.

For myself, I am of the view that focusing on the reductionist aspects of the teachinglearning process that have a technocratic orientation to them, in the absence of the wider ethical and political scenery, is to fail to make the crucial linkage between issues of agency and structure and to relegate teachers to being nothing more than "a $\operatorname{cog}$ in a self-perpetuating machine" (Tom, 1985, p. 38). Teaching, and reflection upon it, has a lot more to do with intentionality and the way in which teachers are able to be active agents (Ross and Hannay, 1986) in making the linkages between economic structures, social and cultural conditions, and the way schooling works.

Countering the dominant view that educational phenomena are natural and capable of detached analysis requires a viewpoint that embraces the essentially political, historical, and theoretical nature of teaching. Such a socially constructed view, which regards teaching as serving certain human interests, posits the entire educational system as potentially part of the arena of the problematic (Tom, 1985) and incorporates reflection that focuses primarily on the way in which schooling contributes (or does not, as the case might be), to the creation of a less oppressive, more just, humane, and dignified society.

The idea that teaching is a political process serving certain interests in demonstrable ways while actively excluding and denying others is not a notion that has general acceptance either among teachers or the wider community (White and White, 1986; Stevens, 1987; Lightfoot, 1973). To some extent this is understandable given the often technicist ways in which the teacher education enterprise trains teachers to engage in the transfer of knowledge to students, rather than to question the notions of power and ideology behind that knowledge (Freedman, 1986). Only rarely have teachers been required (or indeed permitted) to confront the knowledge/power issue. When they do, it is generally in the context of someone else's teaching, not their own. Teachers struggle hard, therefore, to see the importance or even the relevance of "accommodation" and "resistance" in their work, especially in a system which increasingly demands that schools be responsive to the needs of the economy. Because of the way in which capitalist systems in general have been able to ascribe the causes of our economic ills to the personal inadequacies and failings of individuals (illiteracy, lack of incentive, and poor work habits among students) rather than deficiencies of the system itself, it has not been difficult to link this with the systematic failure of schools to meet the needs of industry. The argument is such a compellingly simplistic one that it is proving extremely difficult to dislodge - get students in schools to conform through more compliant forms of 
education, and all our economic woes will disappear. The kind of position represented by these ideas needs to be challenged and roundly critiqued through the kind of reflective process being spoken about here.

Requiring that teachers develop a sense of personal biography and professional history is one way of having them begin to overcome their inertia and unwillingness to question where particular teaching practices came from, and to that extent, no longer accepting teaching actions as natural or common sense and unquestionable. It is to attune them to the fact that perhaps silences on these matters are perhaps not accidental at all, but may be socially constructed responses to wider societal agenda. As Gadamer (1975) argues, understanding practice involves coming to grasp the way in which beliefs and values (which are themselves historical constructions) amount to powerful forces that enable us to ascribe particular meaning and significance to events. Put another way, our experiences as teachers give meaning and significance to events. Put another way, our experiences as teachers have meaning for us in terms of our own historically located consciousness; what we need to do is to work at articulating that consciousness in order to interpret meaning. Failure to understand the breaks and the discontinuities in our history makes it difficult for us to see the shifts in the nature of power relationships, with the result that we end up denying their very existence. Elsewhere I have put it in these words:

Reflection, critical awareness, or enlightenment on its own is insufficient -it must be accompanied by action... [As Freire so aptly put it] reflection without action is verbalism; action without reflection is activism ... [What we need to do is to open up] dialogue between teachers about actual teaching experiences but in a way that enables questions to be asked about taken-for-granted, even cherished assumptions and practices, the reformulation of alternative hypotheses for action, and the actual testing of those hypotheses in classroom situations. (Smyth, 1984, p. 63)

\section{Confronting the Cultural Dispositions of Schooling}

The notion of empowerment (even if it is becoming an overused term) has to do with teachers taking charge of aspects of their lives over which they have been prevented from gaining access in the past (Fried, 1980a). The intention is to critique and uncover the tensions that exist between particular teaching practices and the larger cultural and social contexts in which they are embedded. Willis (1977) expressed it in terms of the social actors themselves reflecting upon, challenging, and refuting, rather than accepting, the structural conditions which envelop their lives. There is a sense in which people who do this embark on a process of becoming different, by thinking critically and creatively to pursue meanings that enable them to make increasing sense of the world in which they live. As Mishler (1986) put it, empowerment entails a shift in the balance of power as participants move beyond the description of the "text" of their teaching, to embrace possibilities for action: "To be empowered is not only to speak one's own voice and to tell one's own story, but to apply the understanding arrived at to action in accord with one's own interests" (p. 119).

There is no longer a preparedness to accept things the way they are, but to see instead, "patterned inequalities, institutional power, ideologies [and] ... the internal dynamics of how a system works, and for whom the system is not functional" (Everhart, 1979 , p. 420). My argument is that teachers are only able to reclaim the power they have lost over their teaching if they place themselves in critical confrontation with their problems. Empowerment through reflection, thus, has less to do with "a handing down of knowledge ... [and is more like] a partnership, a mutual sharing of ideas, intuitions and experiences" (Fried, 1980b, p. 30). In Greene's (1986) terms, this means "a sense of agency is required 
of ... teacher[s]" in which they can "become challengers, when they can take initiatives" (p. 73) and in which schools become places where spaces are created in which worthwhile questions can be asked. For most teachers, this is in stark contrast to the 'delivery of services' mentality created by centralized bureaucratic educational authorities who insist on presenting the educational world in terms of:

... one rank of people (service deliverers) who have been trained and hired to treat the rest. They diagnose our problems, assess our needs, and then provide us with anything from a prescription to an entire program to fix what's lacking, or leaking, in us. (Fried, 1980a. p. 4)

Simon (1987) expressed the way in which teachers become empowered through reflection:

It literally means to give ability to, to permit or enable. When we hear the word empowerment used in education, it is usually being employed in the spirit of critique. Its referent is the identification of oppressive and unjust relations within which there is an unwarranted limitation placed on human action, feeling and thought. Such limitation is seen as constraining a person from the opportunity to participate on equal terms with other members of a group or community to whom have accrued the socially defined status of "the privileged," "the competent." ... To empower is to enable those who have been silenced to speak. (p. 374)

According to Anderson (1987), beyond an ill-defined and rhetorical call for teacher empowerment, there have been few indicators about how teachers themselves "can reflect on the structural conditions that inform their practice" (p. 14). Whether we are talking about preservice or inservice teacher education matters little at this stage. What is important is the stance taken toward knowledge about teaching: who has the right to create it, under what circumstances, and what are the implications of that knowledge on the working lives of people in classrooms. If teachers (or those in training) are denied the opportunity to articulate, critique, and culturally locate principles about their own (or one another's) teaching, then, politically speaking, such teachers are being treated no differently than disempowered workers who have historically been oppressed and denied access to power over their work.

If consciousness raising is in fact about teachers becoming aware of their own alienation and coming to recognize the nature and sources of the forces that keep them subjugated, then as Harris (1979) says, this has to start with their sketching out the contours of actual situations and posing problems about those concrete situations. This process of distancing themselves from classroom events and processes can be difficult and perplexing for teachers (Pollard, 1987) because classrooms present such a kaleidoscope of events that it is difficult for teachers to obtain a stable image of themselves and of the interactive part they play in the creation of those events. Before we can engage teachers in untangling the complex web of ideologies (Berlak, 1987) that surround them in their teaching, they first need to focus on those manifestations of their teaching that perplex, confuse, or frustrate them; that is to say, the practicalities of the here-and-now that teachers pride themselves in being so vitally concerned about.

If teachers are going to uncover the nature of the forces that inhibit and constrain them, and work at changing those conditions, they need to engage in four forms of action with respect to their teaching (each of which has its origins, broadly speaking, in the work of Paulo Freire). They can perhaps be best characterized by a number of sequential stages that can be linked to a series of questions: 
1. Describe.... what do I do?

2. Inform .... what does this mean?

3. Confront .... how did I come to be like this?

4. Reconstruct ... how might I do things differently?

\section{Describing}

Starting with the hermeneutic notion that teaching is a form of text (Gordon, 1988) to be described and then untied (Young, 1981) for the meaning it reveals provides a form of accessibility that has a lot of appeal to teachers. Because teaching is the kind of activity that can only be adequately explicated and critiqued in a post-factum manner, Elliott (1987) argues that "rational action is logically prior to rational principles" (p. 151). The latter, he says, "are the result of reflection on the former" (p. 151), and any critique of teaching must therefore be in the context of practice if it is to go beyond being partial. In essence, the claim is that to articulate adequately the principles that lie behind teaching, teachers must start with a consideration of current practice as the way of gaining entree to the "knowledge, beliefs, and principles that [they] employ in both characterizing that practice and deciding what should be done" (p. 15i). Both Harris (1986) and Bonser and Grundy (1988) claim that written codification can be a powerful guiding device for practitioners engaging in reflective deliberation.

As teachers reflect about their own (or one another's) teaching, they describe concrete teaching events. The teachers I have worked with (Smyth, 1987b; Smyth, 1988) use a journal or diary (Holly, 1984; Tripp, 1987) as a way of building up an account of their teaching as a basis for analysis and discussion with colleagues. Having to write a narrative of what was occurring in confusing, perplexing, or contradictory situations helps them to organize an account of their teaching in a way that is crucial to their finding and speaking their own voices (McDonald, 1986). These descriptions don't have to be complex or in academic language; on the contrary, if there is to be any genuine ownership by teachers, it is important that such descriptions be in their own language (cf. Lortie, 1975). The rationale is that if teachers can create a text that comprises the elements of their teaching as a prelude to problematizing it, then there is a likelihood that they will have the basis upon which to speak with one another so as to see how their consciousness was formed, and how it might be changed. Creating personalized narratives is also a way of guarding against the rampant "intellectual imperialism" (Harris, 1979) so prevalent in teaching, whereby outsiders provide the packaged answers to the issues that are non-questions for teachers. In Shor's (1980) terms, when teachers keep journals they are able to "extra-ordinarily re-experience the ordinary" in a way that is clearly based on a sense of the concrete in their working lives, but in a manner that enables them to see how the elements of particular situations alienate and confuse them and impose real "limit situations" (Fay, 1977) on what it is possible for them to do.

\section{Informing}

When teachers describe their teaching, it is not an end in itself; it is a precursor to uncovering the broader principles that are informing (consciously or otherwise) their classroom action. As Kretovics (1985) put it, it is a way of beginning to confront the "structured silences" that abound in teaching. Developing narratives is a way of uncovering what Argyris and Schon (1977) called "theories-in-use," what Hirst (1983) labelled "operational theories," or what Tripp (1987) has characterized as "local theories." By whatever term we choose to describe them, when teachers engage in the activity of unpacking descriptions of their teaching in order to make a series of "it looks as if ..." 
statements, then they are really recapturing the pedagogical principles of what it is they do. For example, on the basis of descriptions of the way a teacher treats children, it could be said that such a teacher holds a view of classroom management that says "the extent to which a teacher is going to have discipline problems is related to factors like the consistency and firmness of his or her reactions to breaches of classroom rules, the types of punishment he or she metes out, and their severity" (Gordon, 1988, p. 431). In trying to work out their operational theories, teachers are in effect seeking to develop defensible practical principles "grounded in a largely tacit knowledge of complex and particular situations" (Elliott, 1987. p. 152). Such theories or thematic representations may well fall short of being generalizable, but the contradictions they contain may nevertheless be highly significant in explaining the nature of idiosyncratic work contexts. What teachers are trying to do in this process is to move their teaching out of the realm of the mystical, as it were, into a situation in which they are able to begin to see through discussion with others the nature of the forces that cause them to operate in the way they do and how they can move beyond intellectualizing the issues to concrete action for change.

Developing short-range theories or explanatory principles about practice is not without its own set of complex problems and impediments, a major one being the generally enforced separation of theory from practice. Most educational research assumes that theories about teaching are developed by people from outside of classrooms and then transfused into classrooms to be applied by teachers. Such an applied view of the nature of research is, to say the least, highly problematic in that it takes no account of the extensive experiential wisdom possessed by most teachers. Carr (1982) speaks in terms of the prevalent but quite erroneous view of educational theory as being akin to a collage of "maps, guides, itineraries and rule-books produced in some far off land and then exported to the 'world of practice' so that its inhabitants can understand where they are, what they are doing and where they are supposed to be going" (p. 26). The problem, then, is primarily a political one of who has the legitimate right to define what counts as knowledge about teaching. While teachers may have been reluctant in the past to be seen as publicly exercising that claim, others outside of classrooms have been far less reticent. As Kohl (1983) so aptly put it:

Unless we [as teachers] assume the responsibility for theory making and testing, the theories will be made for us by .... the academic researchers and many other groups that are simply filling the vacuum that teachers have created by bargaining away their educational power and giving up their responsibility as intellectuals. (p. 30)

\section{Confronting}

Theorizing and describing one's practice is one thing, but being able to subject those theories to a form of interrogation and questioning that establishes something about their legitimacy and their legacy is altogether another matter. Yet, if we are to be clear about what it is that we do as educators, and why we do it, then it is imperative that we move to this stage. Above all we need to regard the views we hold about teaching not as idiosyncratic preferences, but rather as the product of deeply entrenched cultural norms that we may not even be aware of. Locating or situating teaching in a broader cultural, social, and political context amounts to engaging in critical reflection about the assumptions that underlie those methods and classroom practices. Regarded this way, teaching becomes less of an isolated set of technical procedures, and more of a historical expression of shared values about what is considered to be important about the nature of the educative act. When teachers write about their own biographies and how they feel these have shaped the construction of their values, then they are able to see more clearly how social and institutional forces beyond the classroom and school have been influential. 
As a way of providing some structure, teachers can approach the confrontation of local theories of teaching through a series of guiding questions, that might include the following:

- What do my practices say about my assumptions, values, and beliefs about teaching?

- Where did these ideas come from?

- What social practices are expressed in these ideas?

- What is it that causes me to maintain my theories?

- What views of power do they embody?

- Whose interests seem to be served by my practices?

- What is it that acts to constrain my views of what is possible in teaching? (Smyth, 1987c)

In Freire's (1972) terms this amounts to a way of problematizing teaching by asking poignant questions about the "social causation" (Fay, 1977) of those actions. Untangling and reevaluating taken-for-granted (even cherished) practices require breaking into well entrenched and constructed mythologies that may not always be easily dislodged.

\section{Reconstructing}

Being able to locate oneself both personally and professionally in history in order to be clear about the forces that have come to determine one's existence, is the hallmark of a teacher who has been able to harness the reflective process and can begin to act on the world in a way that amounts to changing it. This amounts to being able to see teaching realities not as immutable givens but as being defined by others, and as essentially contestable. If teachers, and those aspiring to enter teaching, are to experience their lives in authentic terms, then they will have to expel the internalized images that researchers, administrators, and policymakers are so deft at perpetuating. By constructing portrayals of their own teaching that are embedded in the particularities of that teaching, they are able to gain a measure of control through self-government, self-regulation, and self-responsibility that will enable them to trumpet the virtues of "what's best in teaching." Adopting this kind of perspective on reflection is to deny the artificially constructed separation of thought from action, of theory from practice, of mental from manual labor, and ultimately to jettison the false and oppressive view that people outside of classrooms know what is best about teaching. Put quite simply, the people who do the work of teaching should be the same people who reflect upon it.

When teachers are able to begin to link consciousness about the processes that inform the day-to-day aspects of their teaching with the wider political and social realities within which it occurs, then they are able to transcend self-blame for things that don't work out and to see that perhaps their causation may more properly lie in the social injustices and palpable injustices of society, which is to say that deficiencies in teaching can be caused by the manner in which dominant groups in society pursue their narrow sectional interests. Although teachers are by no means a numerically small group in society, it is becoming increasingly clear that they are being acted upon by educational systems and governments in ways that bear an uncanny resemblance to the oppressive treatment meted out to minority groups. Indeed, only when teachers take an active reflective stance (see Freedman, Jackson and Boles, 1983) are they able to challenge the dominant factory metaphor of the way schools are conceived, organized, and enacted. Being reflective, therefore, means more than merely being speculative. It means starting with reality, with seeing the injustices of reality's limits, and beginning to overcome reality by reasserting the importance of learning. 


\section{Conclusion}

To adopt the more expansive and politically informed kind of reflective pose being argued for in this paper is to proceed in a mutually reinforcing direction so that both preservice and inservice teacher education are able to support one another in the effort to reclaim the classroom (Goswami and Stillman, 1987). To argue, for example, that such a reflective process is only possible for experienced teachers who have a lifetime of teaching behind them is to deny a long and sometimes harsh history of being treated in certain ways as students that trainee teachers bring with them to programs of teacher training. These histories are most decidedly worth unpacking in some considerable detail for the more just and humane alternatives they will reveal. Adopting an exclusionist policy over matters like this is only justified in a context that construes teacher education as a narrow process of infusing skills. Besides, to operate otherwise is to ignore what we already know about the powerful socializing effect of the profession on neophyte teachers.

Reflective practitioners and nonreflective practitioners are not two fundamentally irreconcilable groups. Rather, they are at different points in working to overcome the social, cultural, and political amnesia that has gripped the entire teaching profession in recent times (McLaren, 1987). To be sure, there are problems with the reflective approach, but they are not of a kind that have to do with developing a formula and having everyone march in the same direction to the sound of the same drum. The problems are not about ensuring neat and system-wide uniform dissemination of packaged arrangements, but rather have to do with winning the hearts and minds of people committed to a common struggle (Spring, 1977). There are other problems, too, because of the in-built presumption that teachers will necessarily want to become self-aware and act in ways that promote their own interests and those of their students in preference to the forces of dogma and irrationality that blind them to the nature of reality. This, of course, may be quite an erroneous presumption and one that Elbaz (1988) is right to point to as a persisting dilemma. But none of these is adequate justification for not embarking on the process, for as Rudduck (1984) put it: "Not to examine one's practice is irresponsible; to regard teaching as an experiment and to monitor one's performance is a responsible professional act" (p. 6).

\section{References}

Anderson, G. (1987, April). Towards a critical ethnography of educational administration. Paper presented at the annual meeting of the American Educational Research Association, Washington, D.C.

Argyris, C., \& Schon, D. (1974). Theory in practice: Increasing professional effectiveness. London: Jossey-Bass.

Berlak, A. (1987, April). Teaching for liberation and empowerment in the liberal arts: Towards the development of a pedagogy that overcomes resistance. Paper presented at the annual meeting of the American Educational Research Association, Washington, D.C.

Beyer, L., \& Apple, M. (1988). Curriculum: Problems, politics and possibilities Albany: State University of New York.

Bonser, S., \& Grundy, S. (1988). Reflective deliberation in the formulation of a school curriculum policy. Journal of Curriculum Studies, 20 (1).

Carr. W, (1982). Treating the symptoms, neglecting the cause: Diagnosing the problems of theory and practice. Journal of Further and Higher Education, 6 (2), 19-29. 
Connelly, M., \& Clandinin, J. (1988, April). Narrative, experience and the study of curriculum. Paper presented at the American Educational Research Association, New Orleans.

Cruickshank, D. (1985). Uses and benefits of reflective teaching. Phi Delta Kappan, 66, 704-706.

Cruickshank, D., \& Applegate, J. (1981). Reflective teaching as a strategy for teacher growth. Educational Leadership, 38 (7), 553-554.

Dewey, J. (1965). Theory and practice in education (National Society for the Study of Education Yearbook, 1904). In M. Borromann, (Ed.), Teacher education in America: A documentary history. New York: Teachers College Press.

Dippo, D. (1988). Making ethnographic research count. Review of "Becoming Clerical Workers" by Linda Valli. Curriculum Inquiry, 18 (4), 481-488.

Elbaz, F. (1988). Critical reflection on teaching: Insights from Freire. Journal of Education for Teaching, 14 (2), 171-181.

Elliott, J. (1987). Educational theory, practical philosophy and action research. British Journal of Educational Studies, 35, 149-169.

Everhart, R. (1979). Ethnography and educational policy: Love and marriage or strange bedfellows. In R. Barnhardt, et al., Anthropology and educational administration (pp. 409-428). Tucson, AZ: Impresora.

Fay, B. (1977). How people change themselves: The relationship between critical theory and its audience. In T. Ball (ed.), Political theory and praxis: New perspectives (pp. 200283). Minneapolis: University of Minnesota Press.

Freedman, S., Jackson, J., \& Boles, K. (The Boston Womens' Teachers' Group). (1983), Teaching: An imperilled "profession." In L. Shulman \& G. Sykes (Eds.), Handbook of Teaching and Policy (pp. 261-299). New York: Longmans.

Freedman, P. (1986). Don't talk to me about lexical meta-analysis of criterion-referenced clustering and lap-dissolve spatial transformations: A consideration of the role of practicing teachers in educational research. British Educational Research Journal, 12 (2), 197-206.

Freire, P. (1972). Pedagogy of the oppressed. Harmondsworth: Penguin.

Fried, R. (1980a). Empowerment vs. delivery of services. Concord, NH: New Hampshire State Department of Education.

Fried, R. (1980b). Learning in community: An empowerment approach. Concord, NH: Office of Community Education, New Hampshire State Department of Education.

Gadamer, H. (1978). Truth and method. (G. Barden \& J. Cumming's Eds. \& Trans.). New York: Seabury Press.

Gordon, D. (1988). Education as text: The varieties of educational hiddenness. Curriculum Inquiry, 18 (4), 425-449. 
Gore, J. (1987). Reflecting on reflective teaching. Journal of Teacher Education, 38 (2), 33-39.

Goswami, D., \& Stillman, P. (Eds.). (1987). Reclaiming the classroom: Teacher research as an agency for change. Portsmouth, NH: Boynton Cook.

Greene, M. (1986). Reflection and passion in teaching. Journal of Curriculum and Supervision, 2 (1), 68-81.

Harris, 1. (1986). Communicating the character of "deliberation." Journal of Curriculum Studies, 18 (2), 115-132.

Harris, K. (1979). Education and Knowledge: The structured misrepresentation of knowledge. London: Routledge \& Kegan Paul.

Hirst, P. (1983). Educational theory. In P. Hirst (Ed.), Educational theory and its foundation disciplines. London: Routledge \& Kegan Paul.

Holly, M. (1984). Keeping a personal-professional journal. Geelong, Australia: Deakin University Press.

Kohl, H. (1983). Examining closely what we do. Learning, 12 (1), 28-30.

Kretovics, J. (1985), Critical literacy: Challenging the assumptions of mainstream educational theory. Journal of Education, 67 (2), 50-61.

Lightfoot, S. (1973). Politics and reasoning: Through the eyes of teachers and children. Harvard Educational Review, 43 (2), 197-244.

Liston, D., \& Zeichner, K. (1987). Reflective teacher education and moral deliberation. Journal of Teacher Education, 38 (6), 2-8.

Lortie, D. (1975). School teacher: A sociological study. Chicago: University of Chicago Press.

Mackie, R. (1981). (Ed.). Literacy and revolution: The pedagogy of Paulo Freire. New York: Continuum.

McDonald, J. (1986). Raising the teacher's voice and the ironic role of theory. Harvard Educational Review; 56 (4), 355-378.

McLaren, P. (1987). Critical pedagogy and the dream of emancipation. Social Education, 51 (2), 146-150.

Mishler, E. (1986). Meaning in context and the empowerment of respondents. In E. Mishler, Research interviewing: Context and narrative. Cambridge, MA: Harvard University Press.

Pollard, A. (1987). Reflective teaching - the sociological contribution. In P. Woods \& A. Pollard (Eds.), Sociology and teaching: A new challenge for the sociology of education. London: Croom Helm.

Ross, E., \& Hannay, L. (1986). Toward a critical theory of reflective inquiry. Journal of Teacher Education, 37 (4), 9-15. 
Rudduck, J. (1984). Teaching as an art, teacher research and research-based teacher education. Second Annual Lawrence Stenhouse Memorial Lecture, University of East Anglia.

Schon, D. (1983). The reflective practitioner: How professionals think in action. New York: Basic Books.

Schon, D. (1987). Educating the reflective practitioner. San Francisco: Jossey-Bass.

Shor, I. (1980). Critical teaching and everyday life. Boston: South End Press.

Shor, I. (1987). (Ed.). Freire for the classroom. Portsmouth, NH: Boynton/Cook.

Simon, R. (1987). Empowerment as a pedagogy of possibility. Language Arts, 64 (4). $370-382$.

Smyth, J. (1984). Teacher-as-collaborators in clinical supervision: Cooperative learning about teaching. Teacher Education, 24, 60-68.

Smyth, J. (1986). Reflection-in-action. Geelong, Australia: Deakin University Press.

Smyth, J. (1987a). (Ed.). Educating teachers: Changing the nature of pedagogical knowledge. London: Falmer Press.

Smyth, J. (1987b, October). A critical pedagogy of classroom practice. Paper presented at the ninth Curriculum Theorizing and Classroom Practice Conference, Dayton, OH.

Smyth, J. (1987c). Rationale for teachers' critical pedagogy: A handbook. Geelong, Australia: Deakin University Press.

Smyth, J. (1988). Teachers theorizing their practice as a form of empowerment. The Educational Administrator, 30, 27-37.

Spring, J. (1977). A Primer for libertarian education. New York: Free Life Editions.

Stevens, P. (1987). Political education and political teachers, Journal of Philosophy of Education, 21 (1), 75-83.

Tom, A. (1985). Inquiring into inquiry-oriented teacher education. Journal of Teacher Education, 36 (5), 35-44.

Tripp, D. (1987). Theorizing practice: The teacher's professional journal, Geelong, Australia: Deakin University Press.

Walker, S., \& Barton, L. (1987). (Eds.). Changing policies, changing teachers: New directions for schooling, Milton Keynes: O.U.P.

White, J., \& White, P. (1987). Teachers as political activists. In A. Hartnett \& M. Naish (Eds.), Education and society today. London: Falmer.

Willis, P. (1977). Learning to Labour: How working class kids get working class jobs. Westmead, G. B.: Gower.

Young, R. (1981). (Ed.). Untying the text. Boston: Routledge \& Kegan Paul. 